\section{FUNCTION AND FUTURE OF COLONIAL GEOLOGICAL SURVEYS}

$\mathrm{D}$ URING the past few years, attention has been directed, from time to time, in NATURE and elsewhere*, to the importance of the work of geologists, to the widespread ignorance, in Great Britain, of geological science, and to the consequent lack of appreciation of the many services which geologists can and ought to perform for the common good. The immediate seriousness of the position lies' not so much in the fact that this ignorance should prevail among the community at large, as in the realization that it extends into the administrative and governing classes, both civil and military. There is, it seems, a consensus of opinion that this is the existing state of affairs.

While it may be true that it is often recognized, if not very clearly, that there is a connexion between geology and the production of minerals, it is less commonly realized that geologists are able to render equally important, if less obvious, services in furtherance of other activities closely bound up with human welfare, such as agriculture, civil engineering and, not least, questions of water supply.

The discovery of valuable mineral deposits as a direct result of geological exploration provides from time to time a striking illustration of the importance of such a survey; but it is far from easy to demonstrate to the layman the potential value of the day-to-day work carried out by geologists, including the contributions to pure geology made by government servants. It is nevertheless true to say that the connexion between pure and applied geology is a very close one. The rare mineral of yesterday, the occurrence of which has been recorded for scientific reasons, in many cases has acquired later on an unforeseen commercial value. Similarly, the finding of some obscure fossil in the field, and its identification in the laboratory by a skilled palæontologist, may have important and perhaps immediate consequences in industry. The location of good water supplies, a service in many cases requiring the advice of a skilled geologist, is also work the value of which is not easily assessed. Of not less importance, too, is the fact that the geologist who knows his terrain thoroughly is not infrequently able to give advice that results in saving the community large sums of money that otherwise would have been wasted.

All these considerations suggest that a wise and foreseeing government would be well advised to establish and maintain properly staffed and equipped Geological Surveys, particularly in new and relatively little-known territories such as the British Colonies; and to ensure that the scientific side of the work is not unduly subordinated to the more immediate and obvious economic requirements.

Nevertheless, it still seems to be the case that, even in administrative quarters where there is some appreciation of the nature and functions of a Geological Survey, there is still incomplete realization of the purely economic value of the services such a Survey can render, and hence a lack of willingness to

* See Boswell, P. G.H., "The Status of Geology : a Review of Present Conditions", Proc. Geol. Soc., Q.J.G.S., 97, xxxvi-1v (1941); "Geology and the Community", NATURE, 147, 459 (1941). Read, H.' H." "GeO logy and Geologists in the National War Fffort", NATURE, 149, 39 (1942): "Geologists in War Time", NATURE, 149, 282 (1942); "G'To" logy, Geologists and the War Effort" NATURE. 161, 118 '(1943)

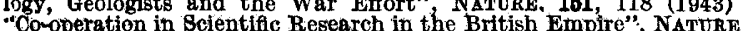
159, 29 (1943). Bafley, E. B., "Geology in the War and After", NATURE, 162, 728 (1943). ensure that Geological Surveys under their control are adequately financed.

The repercussions of this state of affairs on the development of the British Colonial Empire were debated recently at a joint meeting of the Geological Society of London and the Institution of Mining and Metallurgy*, which had been specially convened to discuss the "Contribution of Geological Surveys to Colonial Development, and the Future of Colonial Geological Surveys". The debate centred round an address on this subject given by Sir Edmund Teale, formerly director of the Geological Survey of Tanganyika Territory. Prof. W. G. Fearnsides, president of the Geological Society, occupied the chair during the earlier part of the meeting, and his place was taken later by Sir Lewis Fermor, vice-president of the Institution of Mining and Metallurgy, and formerly director of the Geological Survey of India.

In his opening remarks, Prof. Fearnsides stated that the meeting had been arranged as a result of representations made to the Society by some of its fellows, resident abroad, who, being servants of the State, were dissatisfied with the conditions existing in certain Geological Surveys. In view of the economic functions of Geological Surveys, the Council had thought it desirable to seek the co-operation of the Institution of Mining and Metallurgy, as representing the metal-mining interests in Great Britain, and thereby to secure a much stronger and more professional representation at the meeting.

Sir Edmund Teale first of all pointed out that, in view of the attention now given to post-war planning, the time seemed opportune to discuss the extent to which Geological Surveys can play a part in the economic development of British Colonies. He then spoke at some length on the "complete misconception which seems to exist in high places concerning the purpose, scope, requirements and results of the work of Geological Surveys", in the following terms :

"Profound misconception exists, even among some of the highest of our Colonial officers, about the valuable work that has already been accomplished by these geological departments, and this misconception has resulted, even in the best periods, in the total inadequacy of the financial provision made for essential field work, in the reduction, in more critical times, of the existing staff, and in the failure to fill positions left vacant by the retirement of the heads of the Geological Surveys. The view is held by the officers in charge of the finances of the Colonies that Geological Surveys are not revenue-producing departments. This will appear strange to mining engineers and others familiar with the economic aspects of geological work; but there is abundant evidence of the almost complete unawareness among the chief officers of the Crown of the substantial revenue, besides other benefits, which is the direct result of discoveries of mineral deposits made by these Surveys.

"It is clear, as was shown in a short paragraph in an article in The Times of September 15, 1943, on tropical African Colonies, that in the view of high authorities the work of Colonial Geological Surveys finishes with mapping, and that that work is now nearly complete! Further, in certain Colonies, Geological, Mining, Survey and Lands Departments have all been merged under one Director, and he without any special training or experience in any of these subjects ; many very unsatisfactory situations have thereloy been created. In another Colony,

- Abstr. Proc. Geol. Soc., No. 1399, 11 (Dec. 28, 1943). 
mining and geological sections are combined under a non-technical director selected from the Administration Department. The mining community has never been satisfied with this arrangement nor has the geological section received the support and encouragement it merits. A great lack of uniformity of conditions prevails throughout the Colonies undertaking geological work, notwithstanding the existence of a professedly unified Colonial Geological Service.

"Water-supply investigation suffers from a wide divergence of control in the different Colonies and even a lack of consistent policy within a particular Colony. Thus at one period as many as six departments were engaged independently upon water. supply. The present policy, in general, is to use the Geological Survey to direct these activities, although in one Dependency control has recently been removed, first to the Railway Department and then to the Public Works.

"The temporary or intermittent character of some Geological Surveys, though often the result of varying financial conditions, is also partly attributable to this ignorance of the practical value of geological work. In British Guiana, Jamaica, Nyasaland, Tanganyika, and elsewhere geological work has been intermittent and the gaps have seriously retarded the systematic survey of these territories. In consequence, when certain economic demands arose, there was a lack of preparedness to meet them. Some countries, like Fiji, have never had a Geological Survey, while in others, like Kenya, there was undue delay in establishing one.

"This complete misconception of the purpose and results of geological work is also exemplified in the use of geologists for duties other than those for which they have been trained and which they are engaged to undertake : for example, the using of a geologist as an Inspector of Mines, as a District Commissioner or as an Agricultural Officer, and the overloading of him with routine clerical work or with an undue amount of topographical survey.

"A number of examples might be quoted in which the failure to obtain geological advice upon engineering problems, such as railways, bridge and dam sites, has been very costly, both financially and in the consequent interference with public services.

"A lack of continuity of policy regarding long-range systematic geological work has resulted in a lack of balance whereby an undue amount of attention has at times been given to one branch of survey work at the expense of other equally important branches."

Sir Edmund gave the accompanying statistics of the amount and value of the mineral production of the Colonial Empire.

Table 1 is of particular interest, since it shows the revenue accruing directly to the Colonial authorities through the exploitation of mineral deposits actually discovered by Colonial Geological Surveys. Sir Edmund pointed out that, while the total royalties received from the diamond industry alone in the Gold Coast, up to 1939 , amount to $£ 424,830$, the annual expenditure on geological survey is only

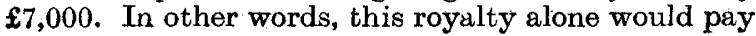
for the cost of the survey for sixty years. In the Colony and Protectorate of Sierra Leone the dis. crepancy, he stated, is even more striking. The Colony at present employs only one geologist, but the estimated value of the mineral production was more than $1 \frac{1}{2}$ million pounds, providing a direct revenue to the Colony of nearly $£ 175,000$.
TABLE 1.-PRODUCTION AND VALUE OF CERTAIN Minerats ReSULTING FROM The DIscoveries of Colonlal Geological SURVers".
Mineral
Production
Value
Remarks
GOLD COAST

Diamond $14,139,683$ carats $£ 7,613,186 £ 424,830$ Productionrepre. to end of March 1939.

Diamond export tax to end of

Manganese $5,341,308$ tons $£ 10,062,594 \quad$ - $\begin{gathered}\text { December, } 1939 \text {. } \\ \text { Manganese ore is }\end{gathered}$ $\begin{array}{ll}\text { ore } & \text { wet ore for the } \\ \text { earlier years and }\end{array}$ dry ore for later years.

\begin{tabular}{|c|c|c|c|}
\hline \multicolumn{4}{|c|}{ SIERRA LEONB } \\
\hline Iron ore & $2,750,000$ tons & $£ 1,497,373^{:}$ & Diamond proflt \\
\hline Diamond & $2,616,104$ carats & $£ 3,275,402 \bullet £ 466,818$ & $\begin{array}{l}\text { Quantity refers } \\
\text { to production, } \\
\text { value to ex- } \\
\text { ports. values of } \\
\text { production not } \\
\text { available, but } \\
\text { should not vary } \\
\text { greatly from ex- } \\
\text { ports. }\end{array}$ \\
\hline
\end{tabular}

\begin{tabular}{|c|c|c|c|}
\hline \multicolumn{4}{|c|}{ NIGERIA } \\
\hline Coal & $5,546,000$ tons & $£ 1,860,000$ & $\begin{array}{l}\text { To end of March, } \\
1939 \text {. Coal min- } \\
\text { ing being a Gov- } \\
\text { ernment indus- } \\
\text { try, the value } \\
\text { refers to ex- } \\
\text { penses incurred } \\
\text { in mining, no } \\
\text { p o of t being } \\
\text { added. }\end{array}$ \\
\hline
\end{tabular}

ESTIMATED RESERVES, NO PRODUCTION YET

Gold CoAST Bauxite 250,000,000 tons.

Nyasaland Bauxite 60,000,000 tons.

${ }^{1}$ Information supplied by the Mineral Resources Department of the Imperial Institute. Figures are cumulative from the earliest recorded production or export. Later figures are not generally available for publication.

2 To end of 1940 : iron ore $£ 2,640,966$; diamond $£ 4,700,272$.

TABLE 2. VALUE OF MINERAL PRODUCTION (IN \& STERLING) OF OERTAIN BRITISH COLONIES AND DEPENDENCIES DURING 1938.

Country Value Principal Minerals with their

Nigeria . . 2,100,000 Tin 1,685,000; gold 177,000; coal

Gold Coast . . 6,267,000 Gold 4,811,000; manganese ore Sierra Leone . . 1,684,240 908,000; diamond 548,000.

Diamond 818,925; iron ore

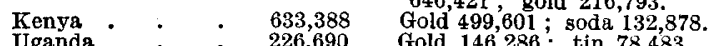

Uganda : $\quad$ : $\quad 226,690$ Gold 146,286; tin 78,483 .

$\begin{array}{lrl}\text { Tanganyika } & 712,730 & \text { Gold 588,679.ं } \\ \text { Northern Rhodesia } 10,683,715 & \text { Copper 10,254,705. }\end{array}$

Northern Rhodesia 10,683,715

Aden : : : 120,971

Palestine : : 330,000 Graphite; excludes salt.

British Malaya : $\mathbf{9}, 970,000 \quad$ Potash and bromine.

British Borneo * $9,970,000$

(Brunei, Sarawak) 980,000

New Guinea (year

June 1939) . - 1,700,000

Fiji $\quad \begin{array}{r}632,000 \\ \text { Trinidad and Tobago }\end{array}$

British Guiana $\quad 697,800$

Tin 7,980,000; iron ore 920,000 .

Petroleum 830,000; gold 130,000.

Gold.

Gold.

Petroleum 2,654,492.

Bauxite 395,190 ; gold 226,337 ; diamond 74,273

The information given above was supplied by the Mineral Resources Department of the Imperial Institute. Quarry products and salt are in general, excluded. The following additional statistics have been derived from other sources.

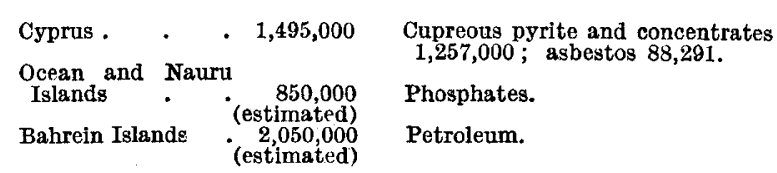

$44,030,435$

There was also a small production in other Colonies : for example, Bechuanaland (gold), Somaliland (salt), Swaziland (asbestos, gold) Papua (gold), Turks and Caicos Islands (sait). 
These figures are but examples, and ignore the actual or potential value of Geological Surveys in other directions, notably in matters of water supply, a theme which Sir Edmund elaborated at some length. He stated that "Those who have not lived and worked in the tropical Dependensies do not, perhaps, realize the extent of country that suffers from the handicap of uncertain and seasonal rainfall. ... Geological advice can in many cases provide a remody and thus assist in a better distribution of the population and in the development of unused tracts of land."

As an example of one of the more indirect results of a Geological Survey, he remarked that in Nigeria the discovery of a coalfield resulted in the building of a direct railway linking the tin-fields with the coast and in the development of one of the best deep-water harbours in West Africa.

Roferring to the Colonies of the British Empire as a whole, Sir Edmund said that "in very few cases has detailed systematic mapping of the standard adopted in Great Britain been attempted, and even in the countries with the strongest and longest established Surveys it can safely be asserted that the greater proportion of the geology shown on the published provisional geological maps is based on reconnaissance traverses. Shortage of staff and the absence of reliable topographical maps are two factors which have handicapped progress in systematic mapping. At the most, fewer than fifty geologists have been available, and at certain periods very many fewer, to deal with an area of about three million square miles-some thirty times the area of the Home Country. Compare this with the staff of over 5,000 trained geologists provided by the Soviet Government !" and, it may be added, with the fifty or so employed in Great Britain alone. As Sir Edmund remarked, the amount of money devoted to Colonial Geological Surveys is astoundingly insignificant in comparison with the benefits they have conferred upon the Empire. Accurate figures are not available, but they probably represent something of the order of a decimal of 1 per cent of the value of the mineral production.

The later part of Sir Edmund's address dealt with certain recommendations, put forward by members of the Institution of Mining and Metallurgy and fellows of the Geological Society, for securing for the Geological Surveys their rightful place in post-war Colonial development.

The meeting was then thrown open for general discussion, and a number of written contributions to the debate were received.

Sir Lewis Fermor, who spoke at some length, pointed out that the total area under the control of the Colonial OAfice is much smaller than Canada, and only of the same order of magnitude as the Indian Empire. Both these countries have found it advantageous to have unified Geological Surveys, yet each Colony, no matter how small, has its own Survey, or none at all ; and this in spite of the fact that some of the Colonies occupy contiguous areas. He also directed attention to the fact that each Colony, no matter whether rich or poor, has to finance its own survey. This fact, combined with the lack of central co-ordination of the work of the several surveys, results in Colonial geological departments varying widely in size, whether expressed by number of personnel or the number of geologists per unit of area, and also in the salaries offered to geologists. Such conditions form a stumbling-block in the way of unifying the Colonial geological services. He sug- gested the grouping of the Colonies into larger units for geological purposes, and the establishment of a system whereby the emoluments of geologists were not directly related to the ability or otherwise of any particular Colony to pay an adequate salary. A move in this direction, he claimed, especially if it carried with it possibilities of promotion with transfer to other Colonies, would lead to an improvement in the morale of Colonial geological officers. It would also benefit not merely the officers concerned but, ultimately, the Colonies themselves.

A number of other points were raised during the course of the debate. One speaker directed attention to the tendency for the more ambitious and energetic geologists to leave government service to work for private mining companies, where better treatment and higher salaries were received; and another instanced the case of a highly successful Canadian mining company that thought it worth while to employ more geologists on its staff than the total number of government geologists in all our African Colonies.

A later speaker mentioned the Island of Trinidad, which, in spite of its valuable oil resources, has not been subjected to a general geological survey since 1860. As a consequence, when, during the present War, it became a base for American forces, and the question of water supplies for the northern part of the land arose, the Colonial authorities had no government geologist to advise them and had to turn for aid to the oil geologists. It was pointed out that the lack of a single government geological report on the geology of the oilfields there within the last thirty years indicated the lack of interest taken by the Colonial Department in these matters.

Sir Thomas Holland, in a written communication, made the following points. He disposed of the suggestion that the geological mapping of the Colonies might be nearing completion by pointing out that so long as geological science continues to progress and specialize, the geological map will never be finished. So long as mineral values continue to change, as they have done in the past, and no doubt will in the future, for a variety of reasons, so often, too, will parts of the geological map need revision. Sir Thomas also directed attention to the desirability that the information accumulated during the course of the Colonial Geological Surveys should be published in some systematic and organized way, so that it might become readily accessible to the outside geological world for reference and, if necessary, criticism.

Another speaker mentioned the importance of geophysical prospecting as an essential adjunct to a Geological Survey. This, he claimed, is insufficiently recognized, and Colonial Surveys should be adequately equipped in this respect, both instrumentally and in respect of suitably trained staff.

Another contributor to the debate made an eminently practical and valuable suggestion in connexion with the possibilities of air survey in the development of the Colonies. He mentioned that the R.A.F. has accumulated a large staff, highly trained in the modern technique of air photography, and in the interpretation of air photographs, the use of which in prospecting and the interpretation of geological' structure is well recognized; in passing, it may be mentioned that a number of geologists are actually employed on this staff. It is incumbent on the Government, he suggested, and in particular the Colonial Office, when the War ends, to secure the service of these expert technicians and their 
equipment for use in the development of the Colonies.

At the conclusion of the meeting the following resolutions were proposed and carried unanimously :

(1) That this Joint Meeting of the Geological Society of London and of the Institution of Mining and Metallurgy welcomes the attention now being given to the resources of the Colonial Empire and desires to stress the importance of Geological Surveys in the well-being of the Colonies, especially for the development of mineral resources and in connexion with water supply, public works, soil conservation, agriculture and forestry.

(2) That this Meeting views with concern the progressive deterioration of status of certain Colonial Geological Surveys and the discouraging conditions under which these Surveys are now functioning. It is also of opinion that Colonial Government Departments do not fully appreciate the practical value of geology to the community and the need for maintaining the individuality of the Surveys, under the direction of competent and experienced geologists.

(3) That this Meeting advocates : (a) the appointment by the Colonial Office of a Colonial Geological Surveys Advisory Board, (b) the appointment to the staff of the Colonial Office in London of a scientific Director-General of Colonial Geological Surveys, who should report periodically to the Advisory Board and should inspect the work of the Colonial Geological Surveys from time to time.

(4) That this Meeting urges that the deputation appointed by the Councils of the Geological Society and the Institution of Mining and Metallurgy jointly should wait upon the Secretary of State for the Colonies and submit their views with the object of increasing the scope and fostering the welfare of the Colonial Geological Surveys as an essential part of the post-war development programme for the Colonial Empire.

We are informed that the proposed deputation has since been favourably received by the Secretary of State for the Colonies.

While it seems clear that the action taken was well justified, in fairness to the Colonial Office it should be stated that a certain amount of attention has recently been given to the matter. Following on the passing, in 1940, of the Colonial Development and Welfare Act, a Colonial Research Committee was appointed, in June 1942, to advise upon the expenditure of the annual sum of $£ 500,000$ provided by the Act of 1940 as provision for Colonial research, and to assist in co-ordinating the whcle range of research in Colonial studies. This Committee recently published its first progress report (see NaTuRE, 153, 119 ; 1944). In this report it is pointed out that Geological Surveys would come within the Committee's purview, and it is also noted that they do not at present exist in certain Colonies. The Committee further directs attention to the fact that mineral development of Colonies is impossible without accurate topographical surveys. A grant of $£ 7,000$ to enable the Geological Survey of British Guiana to be carried on on a proper basis is recorded in this report; and, according to The Times of December 31, 1943, a further grant of $£ 32,000$ has been made for geological survey work in Nigeria.

The timely aetion taken by the Geologieal Society and the Institution of Mining and Metallurgy will, no doubt, serve a useful purp se in impressing on the Committee the urgent need for further action in this direction.

\section{CANCER RESEARCH IN BRITAIN DURING 1942-1943}

THE twentieth annual report of the British Empire Cancer Campaign was presented recently at a meeting in London. In proposing the adoption of the report, Prof. E. C. Dodds dealt in a general way with the difficulties of presenting the results of scientific research on cancer to the public, and with the complexity of modern experimental biology. $\mathrm{He}$ made particular reference to the success obtained in the treatment of cancer of the prostate with synthetic œstrogens.

\section{Clinical}

Recently American clinicians have obtained good results in the treatment of cancer of the prostate with cestrogenic substances. Similar results have now been seen in Great Britain. In one case treated at the Middlesex Hospital, the results of the American observers have been completely confirmed in the twelve months that the patient has been under treatment. Seven cases have been treated with diethyl stilbœstrol at the Royal Cancer Hospital by Dr. J. Watkinson, in collaboration with members of the honorary staff. In five of these cases there was evidence of secondary deposits in bone and an increase in the acid phosphatase in the blood serum. In these five cases the treatment produced some regression of the primary growth, a fall in the serum acid phosphatase and a reduction in the pain due to metastases. In one patient regression of a lymph node deposit was observed. Two cases appeared to derive no benefit from the treatment, but on the whole the work is most promising.

The Clinical Cancer Research Committee gives an analysis of details of more than a thousand cases of intrathoracic cancer. The analysis in general is in agreement with existing knowledge. The incidence is high among painters, decorators, engineers and mechanics. It is low among clerks and typists. Although 74 per cent of the patients consulted a doctor within three months of the onset of symptoms, 90 per cent died within a year of the time when diagnosis was made.

Experience gained with the million-volt X-ray installation at St. Bartholomew's Hospital indicates that high-voltage therapy is particularly effective in the treatment of cancer of the rectum.

\section{Carcinogenic Agents}

Workers at the Royal Cancer Hospital have found that $1: 2^{\prime}$-diamino $1^{\prime}: 2$-dinaphthyl, which inhibits growth but has not produced tumours at the site of injection or application, induces multiple adenomas of the lung in mice. The substance thus has a remote carcinogenic action. Russian and French workers have obtained tumours in mice remote from the site of injection of extracts of human lung and liver. Many tumours have occurred at the site of injection of extracts of human organs, but such tumours have generally appeared at least twelve months after the beginning of treatment. The agents present in human organs appear to be weak and slow in action. As yet it has been irmpossible to ascertain before test whether a particular organ will give a carcinogenic extract, so that progress in this field has been slow.

Prof. H. N. Green and Dr. F. Bielschowsky have made further studies on the action of the carcinogenic insecticide, 2-acetylaminefluorene. When fed to malo rats, this substance produces tumours of the liver 